\title{
Bone mass of the calvarium
}

\author{
Paolo Simoni • Jennifer Stulko • Selma Ben Mustapha • \\ Laurent Schoysman - Elettra Bianchi • Nadia Withofs • \\ Tudor Racaru • Jo Caers • Victoria Alvarez-Miezentseva
}

Published online: 19 December 2012

(C) ISS 2012

Plasmacytoma of the calvarium is very rare, accounting for the $0.7 \%$ of all plasmacytomas [1-5]. The most common locations are the thoracic and lumbar spine $(30-40 \%$ of cases). Involvement of the hip, femurs, and ribs is less frequent [6].

Plasmacytoma of the calvarium can be indistinguishable from other lytic lesions, especially metastatic disease. Meningioma, eosinophilic granuloma, and dermoid cysts can have similar appearances, although usually in a different clinical context $[10,11]$. Histopathological examination and laboratory tests are necessary to make a definitive diagnosis of plasmacytoma (Fig. 1).

The typical features on imaging are a lytic lesion on Xray examination (Fig. 1 question) $[1,6]$. On computed

The case presentation can be found at doi: 10.1007/s00256-012-1548-5

Answer: Plasmacytoma of the calvarium with evolution into multiple myeloma (MM)

P. Simoni · J. Stulko $\cdot$ S. Ben Mustapha $\cdot$ L. Schoysman •

V. Alvarez-Miezentseva

Service of MSK imaging, University Hospital of Liège (CHU),

Domaine du Sart Tilman Bât. 35,

4000 Liège, Belgium

E. Bianchi

Service of Pathology, University Hospital of Liège (CHU),

Domaine du Sart Tilman Bât. 35,

4000 Liège, Belgium

N. Withofs

Service of Nuclear Medicine, University Hospital of Liège (CHU),

Domaine du Sart Tilman Bât. 35,

4000 Liège, Belgium tomography (CT), plasmacytoma presents as a lytic punched-out lesion with interspersed residual thickened bony trabeculae. Cortical thinning and focal destruction are typical (Fig. 2 question) [2]. On magnetic resonance imaging (MRI), bone plasmacytoma of the calvarium presents as an intramedullary lesion of low to intermediate intensity on T1weighted images and high intensity on $\mathrm{T} 2$-weighted images. Contrast enhancement is usually mild [4-9].

In the presented case, the calvarium plasmacytoma presents a "mini-brain" appearance, due to the presence of low-intensity hypertrophic residual trabeculae interspersed in a relatively homogeneous mass, mimicking the brain sulci.

Major et al. first described the "mini-brain" appearance of plasmacytoma in a series of ten patients with spinal

T. Racaru

Service of Neurosurgery, University Hospital of Liège (CHU), Domaine du Sart Tilman Bât. 35,

4000 Liège, Belgium

J. Caers

Service of Haematology, University Hospital of Liège (CHU), Domaine du Sart Tilman Bât. 35,

4000 Liège, Belgium

P. Simoni $(\bowtie)$

Service of MSK Imaging, University Hospital of Liège,

Domain du Sart Tilman Bât. 45

4000 Liège, Belgium

e-mail: paolo.simoni@chu.ulg.ac.be 
Fig. 1 Surgical biopsy- histological and immunohistochemical specimens. a H\&E stain (original magnification $40 \times$ ); plasma cells exhibit abundant cytoplasm, eccentric nuclei with coarse chromatin. b Immunostain showing plasma cell marker CD138 (brown, Syndecan-1), original magnification $20 \times$; Serotec, B-B4 clone, 1/100 dilution. c Ig Kappa expression (brown) showing a strongly positive monotypic light-chain staining compared to the absence of plasma cell staining for Ig Lambda (d); (original magnification 40×, Dako, 1/8,000 dilution). d Ig Lambda-negative immunostaining (brown); (original magnification $40 \times$, Dako, $1 /$ 8,000 dilution)

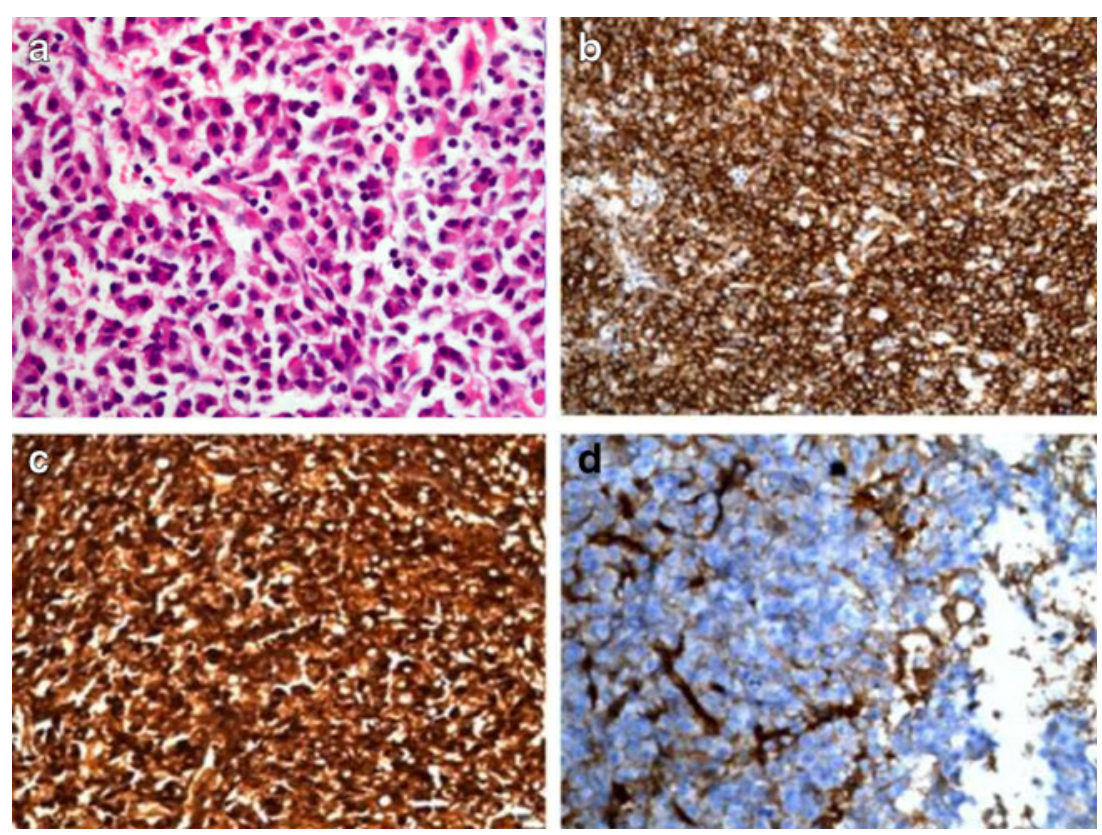

lesions [2]. Since this appearance had not been observed in other bony lesions, they concluded that the "mini-brain" appearance is virtually pathognomonic for bone plasmacytoma of the spine [3]. They argued that thickened trabeculae might be due to mechanical stress from the lytic process [2].

However, the "mini-brain" on MRI has also been described in plasmacytoma of the appendicular skeleton [3]; it has not previously been described in the calvarium. Nevertheless, a "mini-brain" appearance can be retrospectively observed on MRI images of most bone plasmacytomas of the calvarium reported in the literature (see Table 1).

We think that the finding of the characteristic "mini brain" appearance can help to narrow the differential diagnosis of lytic lesions of the skull.

Table 1 Imaging features of BP of the calvarium reported in the English literature

\begin{tabular}{|c|c|c|c|c|c|c|}
\hline & Author (year) & Age/sex & Localization & Lesion size (mm) & $\begin{array}{l}\text { "Mini-brain" } \\
\text { appearance on MRI }\end{array}$ & Sequences available \\
\hline 1. & Nagatomo (1994)[8] & $56 / \mathrm{M}$ & Temporoparietal & $60 \times 40$ & + & $\mathrm{T} 2 \mathrm{w}, \mathrm{T} 1 \mathrm{w}+\mathrm{Gd}$ \\
\hline 2. & Matsuda (1996)[9] & $55 / \mathrm{F}$ & Fronto-temporal & $70 \times 50$ & + & $\mathrm{T} 1 \mathrm{w}, \mathrm{T} 2 \mathrm{w}, \mathrm{T} 1 \mathrm{w}+\mathrm{Gd}$ \\
\hline 3. & $\begin{array}{l}\text { Okamoto }(1997) \\
\text { [first case][6] }\end{array}$ & $72 / \mathrm{F}$ & Occipital & $\begin{array}{l}\text { Small lesion measurement } \\
\text { not provided }\end{array}$ & + & $\mathrm{T} 1 \mathrm{w}, \mathrm{T} 1 \mathrm{w}+\mathrm{Gd}, \mathrm{T} 2 \mathrm{w}$ \\
\hline 4. & $\begin{array}{l}\text { Okamoto (1997)[6] } \\
\text { [second case] }\end{array}$ & $64 / \mathrm{M}$ & Occipital & $60 \times 90$ & + & $\mathrm{T} 1 \mathrm{w}, \mathrm{T} 1 \mathrm{w}+\mathrm{Gd}, \mathrm{T} 2 \mathrm{w}$ \\
\hline 5. & Tanaka (1998)[4] & $55 / \mathrm{M}$ & Frontal & $80 \times 80$ & + & $\mathrm{T} 1 \mathrm{w}, \mathrm{T} 1 \mathrm{w}+\mathrm{Gd}$ \\
\hline 6. & Zigouris (2009)[7] & $78 / \mathrm{F}$ & Temporoparietal & $98 \times 90$ & + & $\mathrm{T} 1 \mathrm{w}, \mathrm{T} 1 \mathrm{w}+\mathrm{Gd}$ \\
\hline 7. & Bakar (2010)[5] & $49 / \mathrm{M}$ & Frontal & $90 \times 85$ & $\begin{array}{l}\text { Low signal linear } \\
\text { images visible }\end{array}$ & $\mathrm{T} 1 \mathrm{w}+\mathrm{Gd}, \mathrm{MR}$ angiography \\
\hline 8. & Gozzetti (2012) [12] & $67 / \mathrm{M}$ & Fronto-parietal & $\begin{array}{l}\text { Large lesion measurement } \\
\text { not provided }\end{array}$ & $\begin{array}{l}\text { Low signal linear } \\
\text { images visible }\end{array}$ & $\mathrm{T} 1 \mathrm{w}+\mathrm{Gd}$ \\
\hline 9. & Simoni (2012) & $48 / \mathrm{M}$ & Frontal & $60 \times 35$ & + & $\begin{array}{l}\mathrm{T} 1 \mathrm{w}, \mathrm{T} 1 \mathrm{w}+\mathrm{Gd}, \mathrm{T} 2 \mathrm{w} \\
\text { FLAIR, T2* }\end{array}$ \\
\hline
\end{tabular}

$+=$ presence of a "mini-brain" appearance

$\mathrm{w}=$ weighted 


\section{References}

1. Kuzeyli K, Duru S, Ceylan S, Aktürk F. Plasmacytoma of the calvarium. A case report. Neurosurg Rev. 1995;18(2):139-42.

2. Major NM, Helms CA, Richardson WJ. The "mini brain" plasmacytoma in a vertebral body on MR imaging. AJR. 2000;175 (1):261-3.

3. Subhas N, Bauer TW, Joyce MJ, Sundaram M. The "mini brain" appearance of plasmacytoma in the appendicular skeleton. Skeletal Radiol. 2008;37(8):771-4.

4. Tanaka M, Shibui S, Nomura K, Nakanishi Y. Plasmacytoma of the calvarium: a case report. Jpn J Clin Oncol. 1998;28(10):626-30.

5. Bakar B, Tekkok IH. Plasmacytoma of the calvarium vault. Turkish Neurosurgery. 2010;22(1):S095-8.

6. Okamoto K, Ito J, Furusawa T, Sakai K, Tokiguchi S, Sato M, Tanaka R, Nemoto K, Oyanagi K. Plasmacytomas of the occipital bone: a report of two cases. Eur Radiol. 1997;7(4):503-6.
7. Zigouris A, Drosos D, Alexiou GA, Fotakopoulos G, Mihos E, Pahatouridis D, Tsiouris S, Fotopoulos AD, Voulgaris S. Primary plasmacytoma of the cranial vault: a case report. Cases J. 2009;2 (1):9154.

8. Nagatomo Y, Uno H, Maeda K, Matsuoka H, Tsuruda T, Okayama A, Tachibana N, Tsubouchi H. Bulky plasmacytoma of the bone with intracranial invasion. Intern Med. 1994;33(6):376-9.

9. Matsuda M, Nakazawa T, Kizuki H, Matsumura K, Nakasu S, Handa J. Plasmacytoma of the calvarium vault-case report. Neurol Med Chir (Tokyo). 1996;36(6):388-92.

10. Simoni P, Meunier B, Deprez M, Racaru T, Martin D. 36-year-old man with sudden severe headache. Skeletal Radiol. 2011;40 (10):1361-2.

11. Meyer JR, Roychowdhury S, Cybulski G, Russell EJ. Intramedullary plasmacytoma of the calvarium base mimicking aggressive meningioma. Calvarium Base Surg. 1997;7(2):101-5.

12. Gozzeti A, Cerase A, Defina M, Bocchia M. Plasmacytoma of the calvarium. Eur J Haematol. 2012;88:369. 